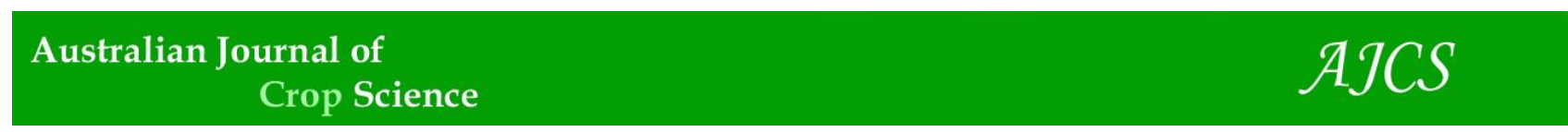

AJCS 11(10):1366-1373 (2017)

ISSN:1835-2707

doi: 10.21475/ajcs.17.11.10.pne732

\title{
Productivity and nutritional quality of Urochloa brizantha cv. BRS Piatã grass fertirrigated with swine wastewater in different seasons of the year
}

\author{
Eder Pereira Gomes ${ }^{1}$, Arthur Carniato Sanches ${ }^{2}$, José Gutemberg Gimenes Deboleto ${ }^{1}$, Fernanda \\ Lamede Ferreira de Jesus ${ }^{2}$, Fernando Campos Mendonça ${ }^{3}$
}

\author{
${ }^{1}$ Federal University of Grande Dourados, Mato Grosso do Sul, Brazil \\ ${ }^{2}$ Graduate Course on Agricultural Systems Engineering, ESALQ/USP, Piracicaba, São Paulo, Brazil \\ ${ }^{3}$ Biosystems Engineering Department, ESALQ/USP, Brazil
}

*Corresponding author: arthur_carniato@hotmail.com

\begin{abstract}
The Brazilian swine production has been grown $38.9 \%$ in the last decade. Inherent to the process, the pollution potential has increased which brings environmental concerns, especially about the final disposal of swine wastewater (SW). In this context, this work aimed to evaluate the responses of 'Piatã' grass (Urochloa brizantha, cv. BRS 'Piatã') to the fertilization with SW, with and without supplemental irrigation. The experiment was carried out for one year from March 2014 to March 2015. The experiment was conducted in a split-plot with a random blocks experimental design with four replications. The treatments in the plots were referred

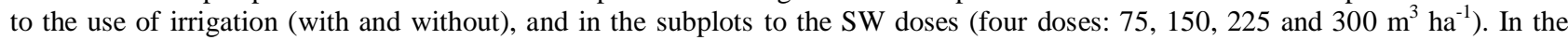
irrigated treatment, the irrigation was fulfilled to re-establish soil moisture in the field capacity $\left(\Theta_{\mathrm{fc}}\right)$. The parameters used to verify the treatments were: total forage yield (TFY), leaves and stems yield (LSY), crude protein rate (CP), neutral detergent fibre (NDF), acid detergent fibre (ADF) and in vitro dry matter digestibility (DivDM). There was a significant increasing effect for doses, reaching a mean TFY of $41.92 \mathrm{Mg} \mathrm{ha}^{-1}$ at the dose of $300 \mathrm{~m}^{3} \mathrm{ha}^{-1}$. The combination of the highest dose of SW combined with supplemental irrigation produced the best results of TFY and LSY with (47.8 and $41.9 \mathrm{Mg} \mathrm{ha}^{-1}$ year ${ }^{-1}$, respectively). Irrigation also led to the best results per cycle, with the highest forage accumulation in spring, 12.28 and $8.55 \mathrm{Mg} \mathrm{ha}^{-1}$ for irrigated and non-irrigated treatments, respectively. In the bromatological parameters, supplemental irrigation led to the highest average levels of CP, ADF and DivDM of $16.7 \%, 33.8 \%$ and $66.5 \%$, respectively. The NDF did not respond to irrigation and SW doses. The research allowed concluding that irrigation and SW fertigation brought quantitative and qualitative benefits to 'Piatã' grass production.
\end{abstract}

Keywords: liquid swine manure, sprinkler irrigation, fertirrigation, forage yield, bromatological analysis, crude protein.

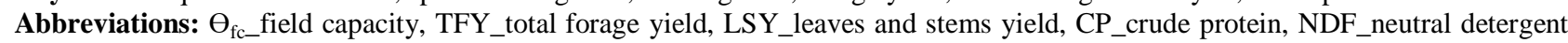
fibre, ADF_acid detergent fibre, DivDM_dry matter digestibility.

\section{Introduction}

Brazil is the fourth largest producer and exporter of pork in the world (Marçal et al., 2016), accounting for 3,360.0 Mg year $^{-1}$ of global pork production (Viancelli et al., 2013). In the last decade, this production increased $38.9 \%$ (ABPA, 2016), raising concerns about the daily concentration of residues of the activity. That production potential (Kessler et al., 2013) is associated wih generation of effluents, mostly in liquid form, with high pollutant potential to water resources, high organic matter load, nutrients and heavy metals (Orrico Junior et al., 2010, 2013; Rodrigues et al., 2010; Vivan et al., 2010; Sousa et al., 2014).

The country has abundant pastures area too, with about 170 million ha ${ }^{-1}$ (Moreira et al., 2014), with cultivated pastures exceeding 60 million hectares, of which $85 \%$ are of the brachiaria genus (Santos et al., 2016). The Piatã grass is a species that has grown the most for high productive responses, including the use of wastewater (Orrico Junior et al., 2013; Gomes et al., 2014; Melo et al., 2016).
Swine wastewater (SW) contains urine, faeces, water, undigested food residues, antimicrobial drug residues and pathogenic microorganisms (Viancelli et al., 2013). When adequately treated, SW may have a high potential for use as fertilizers in agriculture (Kessler et al., 2013; Andrade et al., 2014; Abdoulkader et al., 2015; Egewarth et al., 2015; Homem et al., 2016).

A large problem has been observed due to the increasing water scarcity. In this scenario, the use of wastewater has been considered an essential component on the integrated pastures water management (Abdoulkader et al., 2015). In agriculture, the use of treated wastewater on irrigation may become an alternative for regions facing water scarcity (Dantas et al., 2014). However, it is necessary to know the appropriate application rate for each crop, soil and climate, to reduce nutrient losses (leaching or runoff) and to raise the fertilization efficiency (Orrico Junior et al., 2013).

The productivity of pastures depends on several factors such as the availability of water and nutrients. Tropical 
forage grasses have high potentials of dry matter production, associated with a high nutrient demand. Some reports about 'Piatã' grass present dry matter accumulation between 40 and $98 \mathrm{~kg} \mathrm{ha}^{-1}$ day $^{-1}$ (Nantes et al. 2013, Melo et al., 2016), and even higher values under irrigation, up to $169.4 \mathrm{~kg} \mathrm{ha}^{-1}$ day $^{-1}$ (Gomes et al., 2014). Orrico Junior et al. (2013) observed an increase in the crude protein rate in the 'Piatã' grass under irrigation and application of SW, with values varying from 17.6 to $19.4 \%$, when applying SW doses between 0 and 300 $\mathrm{m}^{3}$ ha $^{-1}$.

The application of pig wastewater in the pastures usually occurs through a mechanized tank, without adequate fertigation, as it requires investments in infrastructure (Andrade et al., 2014). In this context, we tried to evaluate the response of "Piatã" grass after application of different doses of swine wastewater along with additional irrigation.

Thus, the objective of this work was to evaluate the productivity, botanical composition and nutritional quality of 'Piatã' grass under the application of different doses of swine wastewater, with or without irrigation.

\section{Results and Discussion}

\section{Yield parameters of forage dry matter}

The TFY obtained a significant response to the swine wastewater $(\mathrm{p}<0.01)$ represented by a cubic regression (TFY $\left.=3076-10.61 * \mathrm{SW}+0.07 * \mathrm{SW}^{2}-0.0001 * \mathrm{SW}^{3}\right)$ reaching a higher average dose of $3493 \mathrm{~kg} \mathrm{ha}^{-1}$ of TFY. Irrigation showed a significant effect for TFY and LSY at all doses of SW applied (Fig 3). Homem et al. (2016) worked with Brachiaria decumbens in greenhouse and also obtained increasing dry matter yields with increasing doses of SW, with an increase of $11.1 \mathrm{~g} \mathrm{pot}^{-1}$ from the lowest to the highest SW dose.

The TFY without irrigation produced a dry matter variation of $6.8 \mathrm{Mg} \mathrm{ha}^{-1}$ year $^{-1}$, from the lowest to the highest SW dose, with accumulations of 68.6 and $87.2 \mathrm{~kg} \mathrm{ha}^{-1}$ day $^{-1}$ for the doses of 75 to $300 \mathrm{~m}^{3} \mathrm{ha}^{-1}$. The TFY in the irrigated plots obtained a similar variation of $8.9 \mathrm{Mg} \mathrm{ha}^{-1}$ year $^{-1}$, from the lowest to the highest dose. However, the TFY accumulations from 106.7 to $131.1 \mathrm{~kg} \mathrm{ha}^{-1} \mathrm{day}^{-1}$ were below to $151.2 \mathrm{~kg} \mathrm{ha}^{-1}$ day $^{-1}$, where values were reported using SW in 'Piatã' grass in Sorriso-MT (Andrade et al., 2014). Nogueira et al. (2013) studied Tifton 85 irrigated with SW. The highest dose corresponded to $520 \mathrm{~kg} \mathrm{~N} \mathrm{ha}^{-1}$, reporting accumulations of $105 \mathrm{~kg} \mathrm{ha}^{-1}$ day $^{-1}$.

The highest TFY and LSY at all doses can be attributed to the annual mean values of soil water matric potential $\left(\Psi_{\mathrm{m}}\right)$ of 18.9 and $31.1 \mathrm{kPa}$, in irrigated and non-irrigated cultivation, respectively. At different times, the $\Psi_{\mathrm{m}}$ reached peaks higher than $40 \mathrm{kPa}$ in the non-irrigated plots Fig 2. Several authors have indicated $30 \mathrm{kPa}$ as the limit for $\Psi_{\mathrm{m}}$ in pastures (da Fonseca et al., 2007; Sanches et al., 2016; Sanches et al., 2017), because above this value, all the authors observed loss of forage production.

The TFY with irrigation was higher throughout all the study period (Fig 4). Irrigation promoted mean TFY values of 23.8 and $19.2 \mathrm{Mg} \mathrm{ha}^{-1}$ in spring/summer and fall/winter seasons, respectively. Without irrigation, the mean TFY was 15.7 and $12.8 \mathrm{Mg} \mathrm{ha}^{-1}$ in spring/summer and autumn/winter. In addition, irrigation has been shown to increase dry matter yield, even in cold and dry periods, with annual increases ranging from 9 to $20 \mathrm{Mg} \mathrm{ha}^{-1}$ (Gomes et al., 2015; Sanches et al., 2015, 2017; Dantas et al., 2016; Sanches et al., 2016).

During the spring, the highest values of average forage yield (TFY) and leaves and stems (LSY) were observed as 10.41 and $8.74 \mathrm{Mg} \mathrm{ha}^{-1}$, respectively. During the mentioned period, the average value of $\Psi_{\mathrm{m}}$ in the soil of the non-irrigated area was the lowest, remaining under $30 \mathrm{kPa}$, with the highest cumulative rainfall of $436.4 \mathrm{~mm}$ (Fig 2) and minimum temperature above $15^{\circ} \mathrm{C}$ (Fig 1). That may have contributed to the best result between the seasons.

In the plots with $300 \mathrm{~m}^{3} \mathrm{ha}^{-1}$ of $\mathrm{SW}$, the production difference in the seasons was significant, presenting the lowest result during the autumn. During spring/summer and autumn/winter, the average TFY values were 22.2 and 17.7 $\mathrm{Mg} \mathrm{ha}^{-1}$, respectively. With the dose of $75 \mathrm{~m}^{3} \mathrm{ha}^{-1}$, and in the same stations cited, the TFY values reached 17.5 and 14.5 $\mathrm{Mg} \mathrm{ha}^{-1}$. Therefore, from September to March, the dose of $300 \mathrm{~m}^{3} \mathrm{ha}^{-1}$ of SW provided an increase of $27 \%$ in TFY, compared to the lowest dose. During autumn/winter that difference was $22 \%$. Rodrigues et al. (2008) also highlight the preponderant role of fertilization with high nitrogen doses on 'Xaraés' grass, raising leave yield in response to nitrogen application, reaching the highest yield under $150 \mathrm{mg} \mathrm{dm}^{-3}$ of nitrogen.

The LSY (Fig 4) showed a similar behaviour to TFY, with significant responses to irrigation in all cuts. At the dose of $300 \mathrm{~m}^{3} \mathrm{ha}^{-1} \mathrm{SW}$, the LSY values were 41.9 and $27.1 \mathrm{Mg} \mathrm{ha}^{-1}$ for irrigated and non-irrigated plots, respectively. The values represent $87 \%$ and $85 \%$ of the TFY; thus, obtaining the percentage of dead material of 13 and $15 \%$ for the irrigated and non-irrigated cropping treatments. There are similar results found in the literature, 14.6 and $11.4 \%$ of dead material, for Marandu and Tifton 85 grasses, respectively (Trinade et al., 2007; Sanches et al., 2016).

\section{Bromatological parameters: Nutritive value of forage}

No significant differences were found in percentages of NDF and ADF due to SW doses. Although SW showed a significant effect on crude protein rate $(\mathrm{CP})$ with mean values of 16.7 and $14.3 \%$ for irrigated and non-irrigated crops, respectively, irrigation did not have a significant effect (Fig 5). This was a result similar to that found by Homem et al. (2016), who also observed that the SW doses led to an increasing linear behaviour of $4 \%$. The dry matter digestibility "in vitro" was significant for the SW doses and irrigation, with an average value of $66 \%$, close to that found by Melo et al. (2016) on 'Piatã' grass $(66.8 \%)$.

Fonseca et al. (2007) did not observe significant effects between the crude protein rate among the treatments of human wastewater. However, when studying two consecutive experimental years, the author found a similar behaviour, with increasing effects of the applied doses on CP. Normally, the changes may be more significant in quantitative data, as observed in the yield data in a study developed by Fonseca et al. (2007). Irrigation showed significant effects on NDF in cycles 1 and 7 (Fig 6). Orrico Junior et al. (2013), verified a decreasing linear behaviour of NDF under irrigation as a function of the SW doses, reducing by approximately $60.8 \%$ at $0 \mathrm{~m}^{3} \mathrm{ha}^{-1}$ dose to $52.1 \%$ at the $300 \mathrm{~m}^{3} \mathrm{ha}^{-1}$ dose. However, 
Table 1. Means $(\mu)$ and standard error (SE) of SW applied on pasture of 'Piatã' grass. Dourados - MS, $2014-2015$.

\begin{tabular}{|c|c|c|c|c|c|c|c|c|c|c|c|c|c|c|c|}
\hline \multirow{2}{*}{\multicolumn{2}{|c|}{$\mathrm{N}$}} & $\mathrm{P}$ & $\mathrm{K}$ & $\mathrm{Na}$ & $\mathrm{Ca}$ & $\mathrm{Mg}$ & $\mathrm{Cu}$ & $\mathrm{Fe}$ & $\mathrm{Mn}$ & $\mathrm{Zn}$ & SDT & DBO & DQO & $\mathrm{CE}$ & $\mathrm{pH}$ \\
\hline & & & & & & & 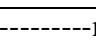 & $\mathrm{mg} \mathrm{L}^{-}$ & & & 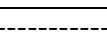 & & & $-\mathrm{S} \mathrm{m}^{-}$ & \\
\hline$\mu$ & 578.9 & 236.4 & 679.8 & 379.2 & 75.7 & 76.2 & 7 & 38.6 & 7.5 & 7.9 & 1897.7 & 1238.6 & 2616.6 & 2.9 & 7.4 \\
\hline SE & \pm 5.23 & \pm 5.15 & \pm 2.62 & \pm 9.38 & \pm 3.71 & \pm 3.95 & \pm 0.58 & \pm 2 & \pm 0.37 & \pm 0.31 & \pm 73.63 & \pm 57.72 & \pm 125.29 & \pm 0.78 & \pm 0.03 \\
\hline
\end{tabular}

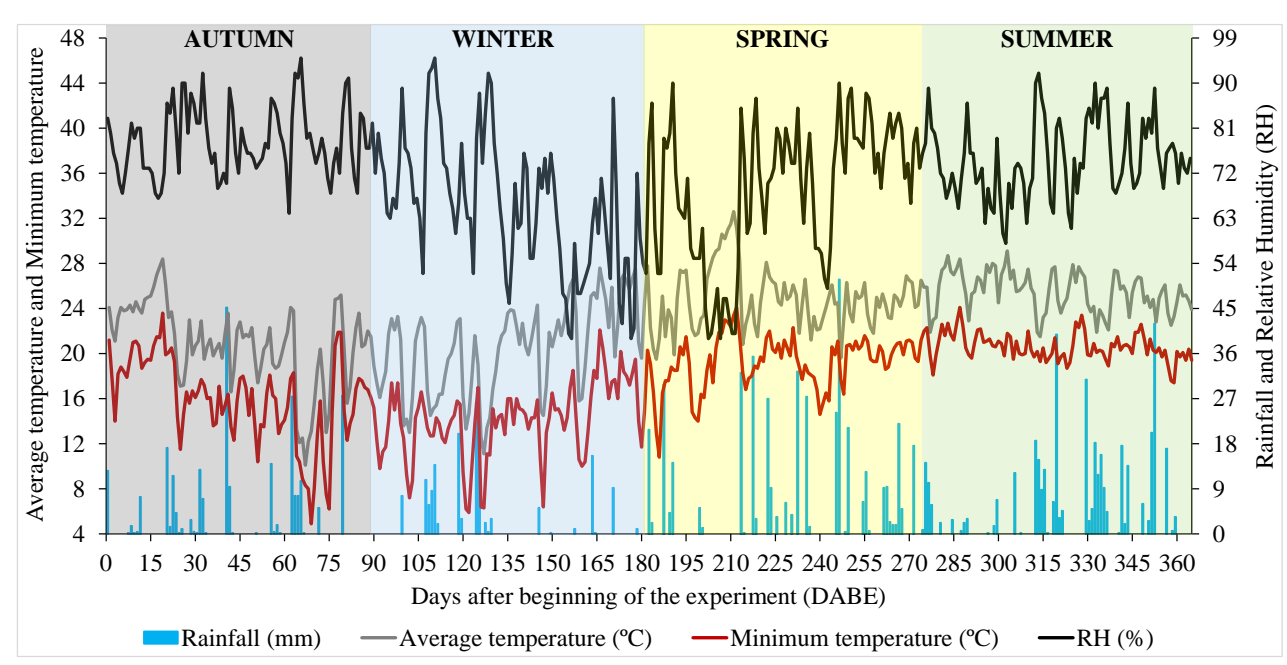

Fig 1. Average and minimum temperature values $\left({ }^{\circ} \mathrm{C}\right)$, Rainfall $(\mathrm{mm})$ and air relative humidity $(\%)$ during the experimental period. Dourados - MS.

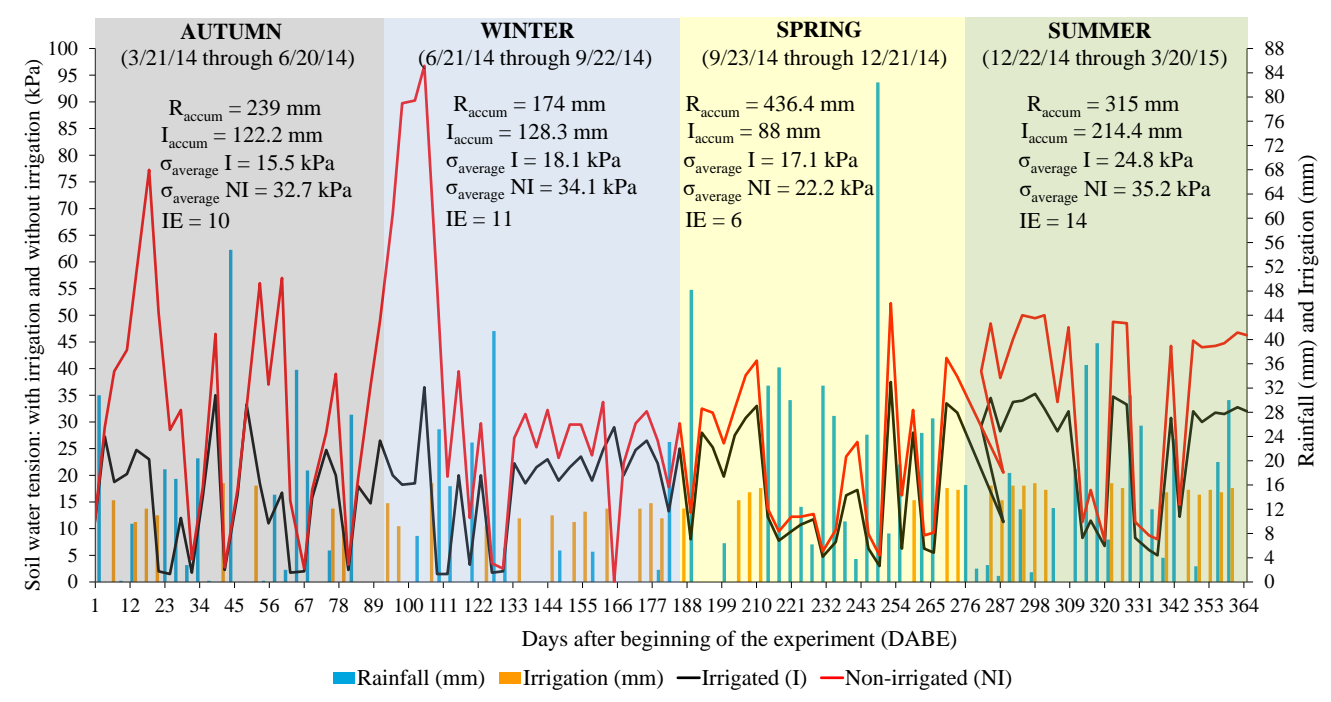

Fig 2. Values of soil water tension $(\sigma)$, rainfall $(\mathrm{mm})$ and irrigation $(\mathrm{mm})$ during the experimental cycle, with 'Piatã' grass, irrigated (I) and non-irrigated. Dourados - MS, $2014-2015$. Subtitle: $\mathrm{IE}=$ Irrigation events, $\mathrm{R}_{\text {accum }}=$ accumulated rainfall, $\mathrm{I}_{\text {accum }}=$ accumulated irrigation. 

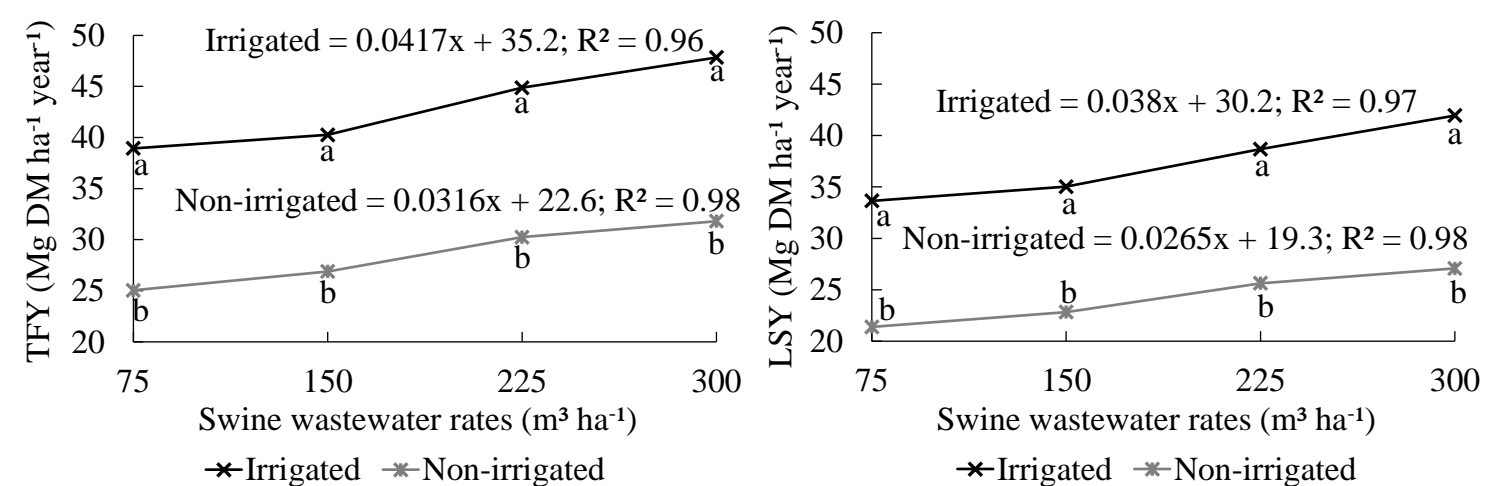

Fig 3. Total Forage Yield (TFY) and Leaf and Stem Yield (LSY) of 'Piatã' grass according to the rates of swine wastewater. Dourados - MS, 2014-2015.
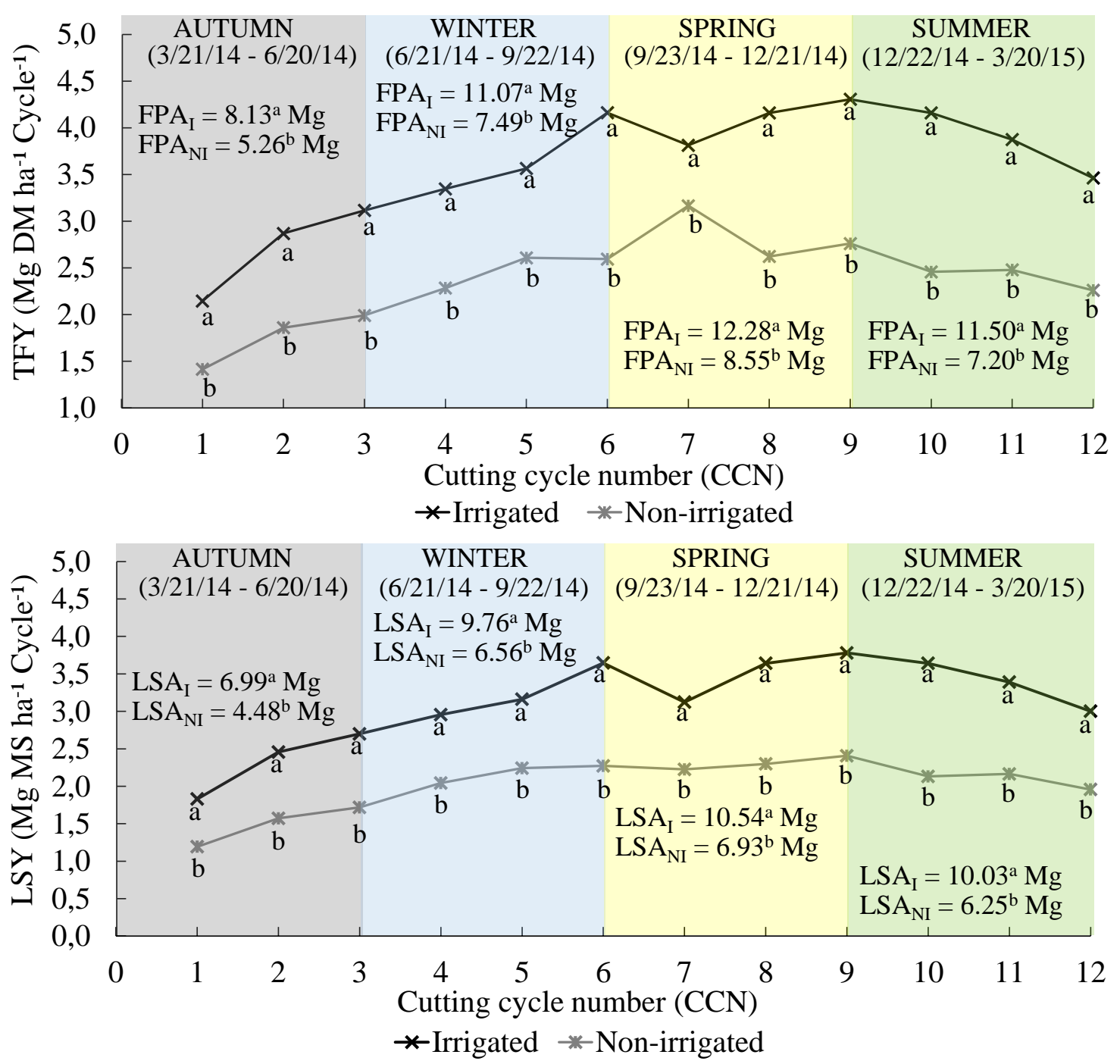

Fig 4. Total Forage Yield per cutting cycle (TFY), Leaf and Stem Yield per cutting cycle (LSY) of 'Piatã' grass according to the irrigation. Dourados - MS, 2014-2015. Subtitle: FPA = Forage Production accumulated, LSP = production accumulated of Leaf. 

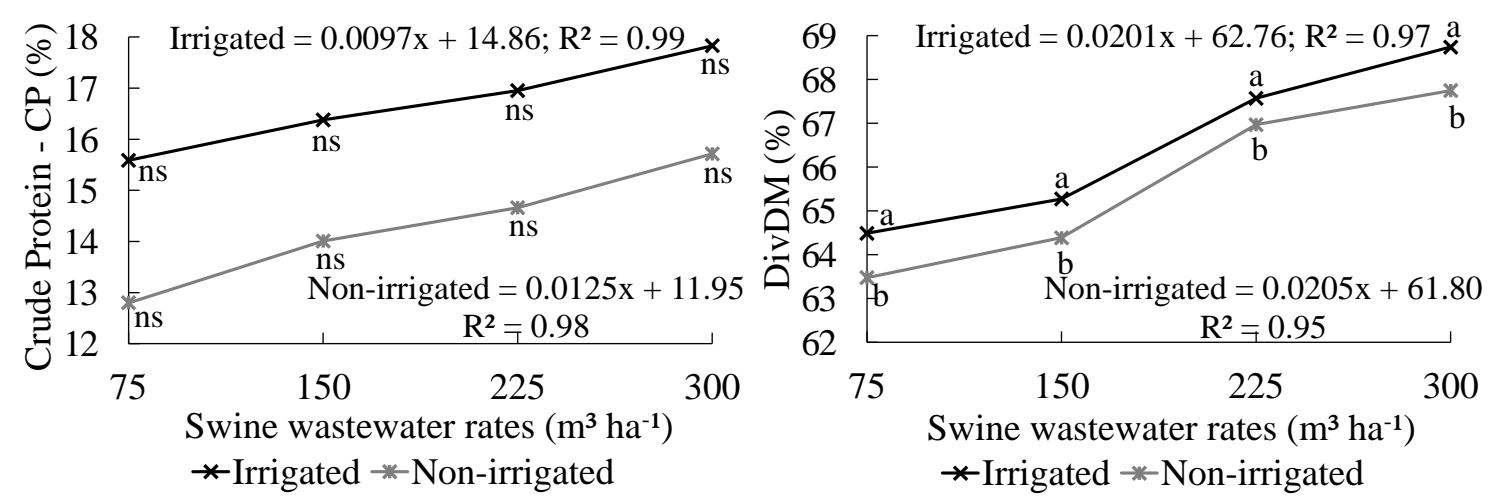

Fig 5. Crude protein rates - CP (A) and digestibility in vitro of dry matter - DivDM (B) of 'Piatã' grass according to irrigation and SW doses. Dourados - MS, 2014-2015.

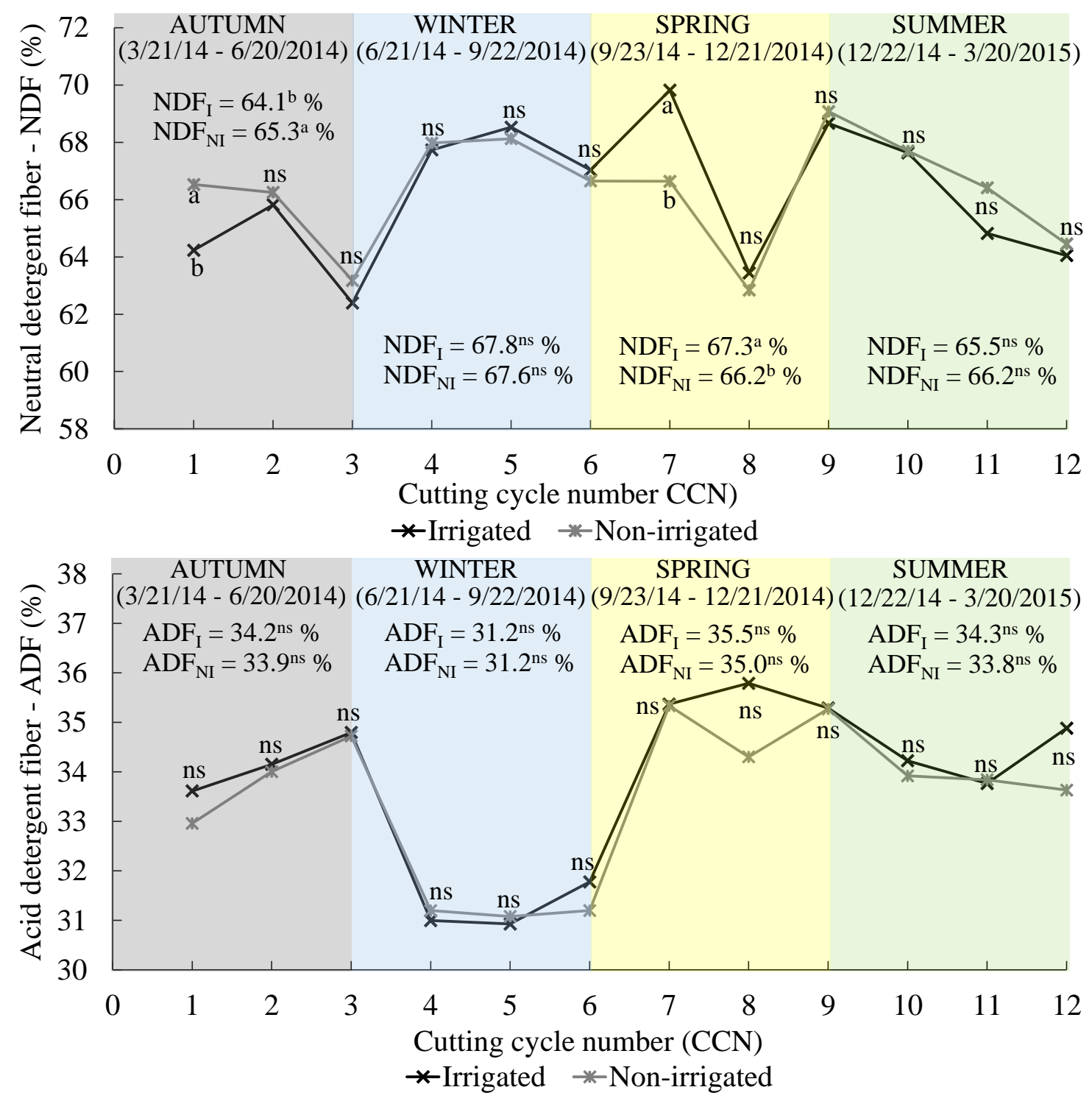

Fig 6. Neutral Detergent Fibre (NDF) per cutting cycle and Acid Detergent Fibre (ADF) per cutting cycle (ADF) of 'Piatã' grass according to the irrigation. Dourados - MS, 2014-2015. 


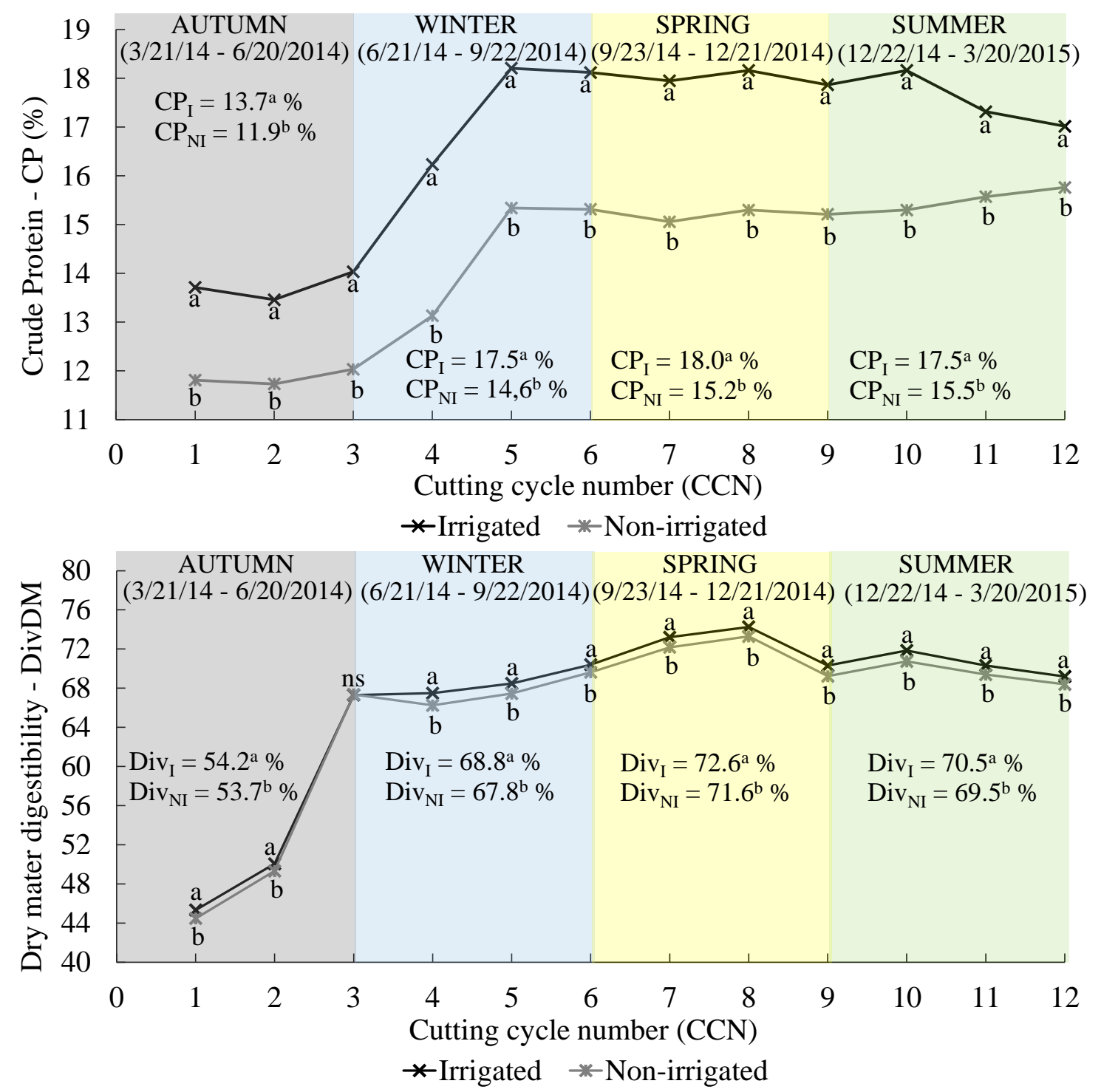

Fig 7. Crude Protein rate (CP) per cutting cycle and Digestibility "in vitro" of dry matter per cutting cycle (DivDM) of 'Piatã' grass according to the irrigation. Dourados - MS, 2014-2015.

the ADF did not present any significant result, corroborating with Dim et al. (2015) and Quintino et al. (2016) studies on 'Piatã' grass, who did not observe changes in the ADF along the time.

The crude protein rates reached the highest averages in the spring/summer seasons, $16.6 \%$ and $16.5 \%$, respectively (Fig $7)$. The highest CP rate $(19.84 \%$ was obtained in the plots irrigated and fertigated with $300 \mathrm{~m}^{3} \mathrm{ha}^{-1}$ of SW. The lowest result $(10.8 \%)$ was obtained in the first cut in the nonirrigated plots with the lowest applied dose $\left(75 \mathrm{~m}^{3} \mathrm{ha}^{-1}\right)$. The doses of 75, 150, 225 and $300 \mathrm{~m}^{3} \mathrm{ha}^{-1} \mathrm{SW}$ produced CPs of $2.79,2.38,2.29$ and $2.13 \%$, respectively, under irrigation. The CP rates corroborated the study of Barnabé et al. (2007), on Marandu grass in Goiânia-GO, reporting that the dose of $300 \mathrm{~m}^{3} \mathrm{ha}^{-1}$ of $\mathrm{SW}$, along with irrigation, promoted the CP rate about $2.7 \%$.

The DivDM presented the best result in the irrigated plots, in most of the experimental period (Fig 7). It was observed that irrigated and non-irrigated values were very close in all cycles, with variations around $1 \%$. Tifton 85 grass also showed similar behaviour with a mean variation of $1.3 \%$ of
DivDM, being significant in some cycles due to irrigation (Sanches et al., 2017).

\section{Materials and methods}

\section{Location, soil classification and climatic characteristics}

The work was carried out at the experimental farm of the Grande Dourados Federal University, in Dourados-MS, from $21^{\text {th }}$ March 2014 to $20^{\text {th }}$ March 2015, comprising one year of experiment.

The place's geographical coordinates are latitude $22^{\circ} 14^{\prime} \mathrm{S}$, longitude $54^{\circ} 59^{\prime} \mathrm{W}$, and altitude of $434 \mathrm{~m}$. According to the Köppen climate classification, the local climate is defined as Cwa, humid mesothermic type, with rainy summer and dry winter. The soil of the experimental area is a Red Dystroferric Latosol (Santos et al., 2013). The soil chemical analysis was performed by collecting samples with an auger in the 0 to $0.40 \mathrm{~m}$ layer, and gave the following results: $\mathrm{pH}_{(\mathrm{H} 2 \mathrm{O})}=4,72 ; \mathrm{P}=13.41 \mathrm{mg} \mathrm{dm}^{-3} ; \mathrm{K}=9.4 \mathrm{mmol}_{\mathrm{c}} \mathrm{dm}^{-3} ; \mathrm{Ca}=$ $4.82 \mathrm{cmol}_{\mathrm{c}} \mathrm{dm}^{-3} ; \mathrm{Mg}=2.86 \mathrm{cmol}_{\mathrm{c}} \mathrm{dm}^{-3} ; \mathrm{H}+\mathrm{Al}=2.93 \mathrm{cmol}_{\mathrm{c}}$ $\mathrm{dm}^{-3} ; \mathrm{Al}=1.2 \mathrm{cmol}_{\mathrm{c}} \mathrm{dm}^{-3} ; \mathrm{V}=74.6 \%$ (bases saturation). 
During the experiment, the following weather data were observed: (a) autumn/winter seasons: cumulative rainfall of $413 \mathrm{~mm}$; average air relative humidity of $71.9 \%$; average and minimum air temperatures of $20.7^{\circ} \mathrm{C}$ and $15{ }^{\circ} \mathrm{C}$, respectively; (b) spring/summer seasons: cumulative rainfall of $751.4 \mathrm{~mm}$; average air relative humidity of $71.8 \%$; average and minimum air temperatures of $24.8{ }^{\circ} \mathrm{C}$ and $20{ }^{\circ} \mathrm{C}$, respectively. The lowest temperature recorded was $4.9{ }^{\circ} \mathrm{C}$ in the autumn/winter period (Fig 1).

\section{Experimental design}

During the experimental period, a weed control was done manually in the plots, and a mechanical control in the surrounding area. The experiment was carried out under a statistical design of random blocks with subdivided plots, known as split-plot designs that means split into parcels with subplots within, and four replications. The treatments in the plots referred to two levels of irrigation (with and without). In subplots, the treatments were four doses of SW applied at each cutting cycle $\left(75,150,225\right.$ and $\left.300 \mathrm{~m}^{3} \mathrm{ha}^{-1}\right)$. So, with four replications, there were 32 experimental unities (subplots), each one with $3 \mathrm{~m}^{2}$.

\section{Irrigation systems and management}

A sprinkler irrigation system was installed, with Agropolo ${ }^{\circledR}$ NY 30 sprinklers spaced $12 \mathrm{~m}$ by $12 \mathrm{~m}$. The application intensity (AI) was determined locally, obtaining a value of 23 $\mathrm{mm} \mathrm{h}^{-1}$ at $196 \mathrm{kPa}$ pressure.

Four tensiometers were installed at $0.20 \mathrm{~m}$ depth in each plot, irrigated and non-irrigated, for the irrigation management and monitoring of the average soil water stress in both the treatments. The readings of soil water matric potential $\left(\Psi_{\mathrm{m}}\right)$ were performed on Tuesdays and Fridays. Irrigations were conducted only when the water tension in the soil reached or exceeded $20 \mathrm{kPa}$. The average values of $\Psi_{\mathrm{m}}$ in the plots with and without irrigation, ranged between 16.8 and $33.4 \mathrm{kPa}$, respectively, during autumn/winter, and between 20.95 and $28.7 \mathrm{kPa}$, respectively, during spring/summer (Fig 2).

The soil moisture at field capacity $\left(\Theta_{f c}\right)$ was considered as the moisture corresponding to the value of $\Psi_{m}=-10 \mathrm{kPa}$. In this way, the irrigation depth (ID) to be applied was determined by the difference between volumetric moisture in the field capacity $\left(\Theta_{f c}\right)$ and the current volumetric moisture $\left(\Theta_{c}\right)$, multiplied by the effective root depth (Z), equal to 400 $\mathrm{mm}$. The irrigation time (IT) at each event, was calculated by dividing the ID by the sprinkler application rate (ID/AR). The values of $\Theta_{c}$ were estimated using the soil water retention curve, obtained with a Richards's extractor in the Laboratory of Water, Soil, Plant and Atmosphere Relations, at the Federal University of Grande Dourados (UFGD), and adjusted by the equation of Van Genuchten (1980):

$$
\Theta_{\mathrm{C}}=0.192+\left[\frac{(0.391-0.192)}{\left[1+\left(0.0003 \Psi_{m}\right)^{0,3240}\right]^{5,6392}}\right] ; \quad\left(\mathrm{R}^{2}=0.99 \text { and } \mathrm{p}<0.01\right)
$$

Where:

$\Theta_{C}=$ current volumetric humidity $\left(\mathrm{cm}^{3} \mathrm{~cm}^{-3}\right)$.

$\Psi_{m}=$ current tension of water in the soil $(\mathrm{kPa})$.

\section{Plant materials and development}

The SW was collected from the third and final decantation pond of a pig termination farm, located near the experimental area, and transported using a properly sealed polyethylene reservoir. The SW applications on pasture were carried out immediately after their arrival at the experimental area, always after the cutting and collection of 'Piatã' grass samples.

The chemical characterization of SW was performed with 12 samples collected at the time of application in the field. They remained frozen at $-10{ }^{\circ} \mathrm{C}$ until the laboratory tests began. The analyses were performed according to the methodology recommended by the Standard Methods for the Examination of Water and Wastewater (APHA, 2012). The contents of $\mathrm{N}_{-} \mathrm{NH}_{4}{ }^{+}$and $\mathrm{N}^{-\mathrm{NO}_{3}}{ }^{-}$were determined by a flow injection analyser. The $\mathrm{N}$-mineral $\left(\mathrm{NH}_{4}{ }^{+}, \mathrm{NO}_{3}{ }^{-}\right)$was considered as $\mathrm{N}$-total because the $\mathrm{N}$-organic was in negligible quantity. The other variables were obtained using an Atomic Absorption Spectrophotometer. The mean results of the SW analyses are shown in Table 1.

The forage cuts were made in 30 days intervals, with a residue height of $20 \mathrm{~cm}$ (after the cut), using a costal mowing. Before cutting, a frame of $0.25 \mathrm{~m}^{2}$ was allocated at the centre of each plot to collect the forage samples. The collected samples were botanically separated in dead material, stem + sheath and leaves. After that they were taken to a forced circulation oven at $65^{\circ} \mathrm{C}$ for 72 hours, in order to determine the total forage yield (TFY), and the Leaf and Stem Yield (LSY).

Subsequently, subsamples of the dried material were taken to the bromatological analysis, obtaining the following components: crude protein rate $(\mathrm{CP}, \%)$, neutral detergent fibre rate (NDF, \%), acid detergent fibre rate (ADF, \%) and in vitro digestibility of dry matter (DivDM, \%), according to Silva and Queiroz (2002). The experimental data were subjected to the analysis of variance ( $\mathrm{p} \leq 0.05)$, and to the regression analysis, when significant differences between SW doses were found. We used the software Assistat 7.7 (Francisco and Carlos, 2016).

\section{Conclusion}

Irrigation promoted higher yields of 'Piatã' grass in both seasons, spring/summer and autumn/winter, producing higher leaves and stems yields. The spring period had the highest total accumulated forage yield, $10.41 \mathrm{Mg} \mathrm{ha}^{-1}$, representing $29.1 \%$ of the total forage yield. Irrigation along with the highest dose promoted the highest total forage yield $(47.8 \mathrm{Mg}$ $\left.\mathrm{ha}^{-1}\right)$, and the highest total leaves and stems yield $(41.94 \mathrm{Mg}$ $\mathrm{ha}^{-1}$ ). Irrigation positively influenced the crude protein rates, which also had a linear response to the applied SW doses. In vitro dry matter digestibility results were linearly responsive to SW rates and were influenced by irrigation.

\section{Acknowledgments}

The authors would thank to the Coordination for Improvement of Higher Education Personnel (CAPES) and National Council for Scientific and Technological Development (CNPq) to scholarship granted for the studies.

\section{References}

Abdoulkader BA, Mohamed B, Nabil M, Alaoui-sossé B, Eric C, Aleya L (2015) Wastewater use in agriculture in Djibouti: Effectiveness of sand filtration treatments and impact of wastewater irrigation on growth and yield of Panicum maximum. Ecol Eng. 84: 607-614.

ABPA. Relatório Anual 2016. Publicações Relatório Anual, p. 136.

Andrade AS, Drumond LCD, Rabelo DML, Appelt MF, Lima JCL, Oliveira VMRD (2014) Crescimento de gramíneas forrageiras fertirrigadas com água residuária de suinocultura. 
Rev Tróp Ciênc Agrár Biol. 8 (2): 59-71

APHA, AWWA, WPCF. Standard methods for the examination of water and wastewater (2012). Washington D.C/USA, American Public Health Association.

Barnabé MC, Beneval R, Lopes EL, Rocha GP, Freitas KR (2007) produção e composição químico- bromatológica da Brachiaria brizantha cv. Marandu adubada com dejetos líquidos de suínos. Ciênc Anim Bras. 8 (3): 435-446.

Dantas GDF, Faria RTDE, Santos GO, Dalri AB, Palaretti LF (2016) Produtividade e qualidade da brachiaria irrigada no outono/inverno. Eng Agríc. 36 (3): 469-481.

Dantas ILDA, Faccioli GG, Mendonça LC, Nunes TP, Viegas PRA, Santana LOGD (2014) Viabilidade do uso de água residuária tratada na irrigação da cultura do rabanete (Raphanus sativus L.). Rev Amb e Água. 9 (1): 109-117.

Da Fonseca AF, Melfi AJ, Monteiro FA, Montes CR, Almeida VVD, Herpin U (2007) Treated sewage effluent as a source of water and nitrogen for Tifton 85 bermudagrass. Agr Water Manage. 87 (3): 328-336.

Dim VP, Alexandrino E, Santos ACD, Mendes RDAS., Silva DPD (2015) Características agronômicas, estruturais e bromatológicas do capim Piatã em lotação intermitente com período de descanso variável em função da altura do pasto. Rev Bras de Saúde e Prod Anim. 16 (1): 10-22.

Egewarth VA, Jonas FE, Maritane P, Edmar SDV, Marcos VMS, Kaian ACK, Gustavo M, Hugo F, Andressa S, Caroline TE (2015) The Effect os swine raising wastewater in the development of millet (Pennisetum glaucum L.), soil and leachate. Afr J Agric Res. 10 (33): 3206-3215.

Francisco DASS, Carlos AVDA. The Assistat Software Version 7.7 and its use in the analysis of experimental data. Afr J Agric Res. 11 (39): 3733-3740, 2016.

Gomes EP, Rickli ME, Cecato U, Vieira CV, Sapia JG, Sanches AC (2015) Produtividade de capim Tifton 85 sob irrigação e doses de nitrogênio. Rev Bras Eng Agr e Amb. 19 (4): 317323.

Gomes EP, Silva LF, Deboleto JGG, Dias DKU, Goes RHTB, Barboza VC (2014) Produtividade e qualidade do capim Piatã sob doses de dejeto suíno líquido tratado na presença e ausência de irrigação. Cad Agroec. 9 (4): 1-10.

Homem BGC, Tavares VB, Almeida Neto OBD, Condé MS, Ferreira IM, Silva MD, Lara MAS (2016) man. Semin Ciênc Agr. 37 (4): 25-39.

Kessler NCH, Sampaio SC, Sorace M, Do Prado NV, Palma D, Da Cunha E, Hamann AL (2013) Swine wastewater associated with mineral fertilization in blackoat (Avena sativa) cultures: $8^{\text {th }}$ production cycle. J Food Agric Environ. 11 (2): 14371443.

Marçal DA, Abreu RCD, Cheung TL, Kiefer C (2016) Consumo da carne suína no brasil: aspectos simbólicos como determinantes dos comportamentos. Rev Agron e Meio Amb. 9 (4): 989-1005

Melo JC, Alexandrino E, Paula Neto JJ, Rezende JM, Silva AAM, Silva DV, Oliveira AKR (2016) Comportamento ingestivo de bovinos em capim-piatã sob lotação intermitente em resposta a distintas alturas de entrada. Rev Bras de Saúde e Prod Anim. 17 (3): 385-400.

Moreira CAA, Pereira DH, Coimbra RA, Moreira DA (2014) Germinação de gramíneas forrageiras em função da inoculação de bactérias diazotróficas. Sci Elec Arch. 6: 90-96.

Nantes NN, Euclides VPB, Montagner DB, Lempp B, Barbosa RA, Gois POD (2013) Desempenho animal e características de pastos de capim-piatã submetidos a diferentes intensidades de pastejo. Pesqui Agropecu Bras. 48 (1): 114-121.

Nogueira SF, Pereira BFF, Gomes TM, De Paula AM, Dos Santos JA, Montes CR (2013) Treated sewage effluent:
Agronomical and economical aspects on bermudagrass production. Agr Water Manage. 116: 151-159.

Orrico Junior MAP, Orrico ACA, Centurion SR, Sunada NDS, Vargas Junior FMD (2013) Características morfogênicas do capim-Piatã submetido à adubação com efluentes de abatedouro avícola. Ciênc Rural. 43(1): 1-6.

Orrico Junior MAP, Orrico ACA, Júnior JDL (2010) Avaliação de parâmetros da biodigestão anaeróbia de dejetos de suínos alimentados com dietas à base de milho e sorgo. Eng AgrJaboticabal. 30 (4): 600-607.

Quintino ADAC, Abreu JG, Almeida RG, Macedo MCM, Cabral LDS, Galati RL (2016) Valor nutritivo de silagem de capimPiatã em monocultivo e em consórcio com sorgo de corte e pastejo. Ciênc Anim Bras. 17 (2): 185-191.

Rodrigues RC, Mourão GB Brennecke K, Luz PHC, Herling VR (2008) Produção de massa seca, relação folha/ colmo e alguns índices de crescimento do Brachiaria brizantha cv. Xaraés cultivado com a combinação de doses de nitrogênio e potássio. Rev Bras Zootecn. 37 (3): 394-400.

Rodrigues LS, Silva IJD, Zocrato MCDO, Papa DN, Sperling MV, Oliveira PRD (2010) Avaliação de desempenho de reator UASB no tratamento de águas residuárias de suinocultura. Rev Bras Eng Agr Amb. 14 (1): 94-100.

Sanches AC, Gomes EP, Rickli ME, Fasolin JP, Soares MRC, Goes RHTBD (2015) Produtividade e valor nutritivo do capim Tifton 85 irrigado e sobressemeado com aveia. Rev Bras Eng Agr Amb. 19 (2): 126-133.

Sanches AC, Gomes EP, Rickli ME, Friske E (2016) Produtividade, composição botânica e valor nutricional do tifton 85 nas diferentes estações do ano sob irrigação. Irriga. 1 (1): 221-232.

Sanches AC, Gomes EP, Rickli ME, Friske E, Fasolin JP (2017) Produtividade e valor nutritivo de tifton 85 durante primavera e verão, sob irrigação e doses de nitrogênio. Eng Agr-Jabotical. 37 (2): 246-256.

Santos DC, Guimarães Júnior R, Vilela L, Pulrolnik K, Bufon VB, França AFS (2016) Forage dry mass accumulation and structural characteristics of Piatã grass in silvopastoral systems in the Brazilian savannah. Agric Ecos Env. 233 (): 16-24.

Santos HG, Jacomine PKT, A, Lumbreras JF, Coelho MR, Almeida JAD, Cunha TJF, Oliveira JBD (2013) Sistema brasileiro de classificação de solos. Embrapa, Rio de Janeiro.

Silva DJ, Queiroz AC (2002) Análise de Alimentos (métodos químicos e biológicos). 3.ed., Imprensa Universitária da UFV, $235 \mathrm{p}$.

Sousa FA, Campos AT, Silva EDB, Mara A, Gandini M, Corrêa JM (2014) Redução do potencial poluidor de dejetos de suínos em lagoas de estabilização em série. Biosc J. 30 (1): 65-73.

Trindade JC, Silva SC, Souza Junior SJ, Giacomini AA, Zeferino CV, Guarda VA, Carvalho PCF (2007) Composição morfológica da forragem consumida por bovinos de corte durante o rebaixamento do capim-Marandu submetido a estratégias de pastejo rotativo. Pesqui Agropecu Bras. 42 (6): 883-890.

Van Genuchten MT (1980) A closed form equation for predicting the hydraulic conductivity of unsaturated soils. Soil Scienc Soc Amer J. 44: 892-898.

Viancelli A, Kunz A, Steinmetz RLR, Kich JD, Souza CK, Canal CW, Coldebella A, Esteves PA, Barardi CRM (2013) Performance of two swine manure treatment systems on chemical composition and on the reduction of pathogens. Chemosphere 90 (4): 1539-1544.

Vivan M, Kunz A, Stolberg J, Perdomo C, Techio VH (2010) Eficiência da interação biodigestor e lagoas de estabilização na remoção de poluentes em dejetos de suínos. Rev Bras Eng Agr Amb. 14 (3): 320-325. 